

\title{
School professional practices to reduce the educational problems of the Preparatory stage students from the teachers' perspective
}



${ }^{(*)}$ Assistant Professor of Educational Psychology, the National Center for Educational Research and Development. 
School professional practices to reduce the educational problems of the Preparatory stage students from the teachers' perspective

.$\wedge 7$.

البحث التربوي 


\section{المركن القومي للبحوث التبويةوالتنمية}

\section{الممارسات المهنية المدروسية للمد هن المشكلات التهمايميهة لدى \\ طلاب المرحلة الإعدادية هن وجهة نظر المهلمين}

\section{ملخص البحث:}

هدف البحث الحالي إلى تحديد المشكلات التعليمية المهمة التي يواجهها الطلاب في مدارسهم، وتقديم بعض الممارسات المهنية في المدارس التي قد يستخدمها المهنيون الذين يعملون في المدارس للحد من هذه المشكلات التعليمية. وشارك عدد

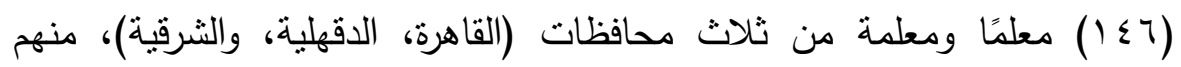
(1) معلمة و(10) معلمًا بالمدارس الإعدادية في الإجابة عن أسئلة استبانة الممارسات المهنية المدرسية (SPPQ)، وهي عبارة عن استبيان يجاب عنه ذاتيًا، وتتكون من (\&V) مفردة تعكس الممارسات المهنية للحد من عدد (T) مشكلات تعليمية، هي: مستوى التحصيل المنخفض، والغش، وعدم التركيز، والهروب من

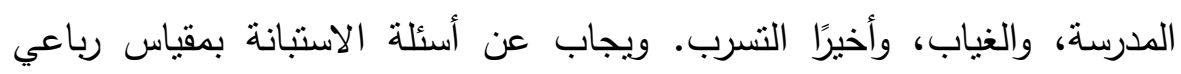

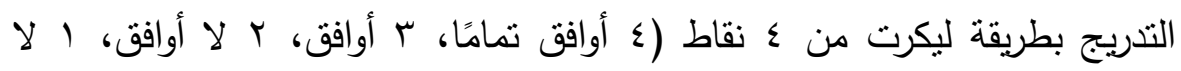
أوافق تمامًا) . وحققت الاستبانة خصائص سيكومتربة مقبولة تتعلق بالصدق والثبات. تم جمع البيانات وتحليلها باستخدام برنامج الحزمة الإحصائية 23.0 SPSS.

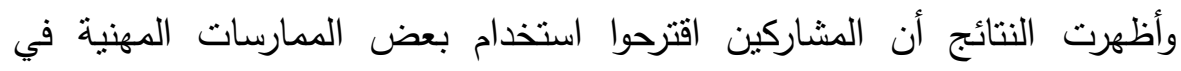
المدارس لتقليل المشكلات التعليمية للطلاب. كما بيَّنت وجود اتفاق بين المشاركين وفقًا للنوع الاجتماعي على بعض الممارسات المهنية في المدرسة للحد من لان المشكلات التحليمية للطلاب، ووجود بعض الاختلافات فيما بينهم في البعض بل الآخر ، وقدم البحث مجموعة من التوصيات والمقترحات البحثية المستقبلية. الكلمات المفتاحية: الممارسات المهنية المدرسية، المشكلات التربوية، طلاب منبه المرحلة الإعدادية. .$\wedge V$. 
School professional practices to reduce the educational problems of the Preparatory stage students from the teachers' perspective

. ^ᄉ.

البحشث التريوي 


$$
\text { المركن الثومي للبحوث التبويةوالنمية }
$$

\title{
School professional practices to reduce the educational problems of the Preparatory stage students from the teachers' perspective
}

\author{
Dr. Mohamed Ghazy Al-dessuky ${ }^{(*)}$ \\ Introduction
}

Early adolescence - which corresponds to the preparatory stage of the educational hierarchy - is particularly important for educators and researchers as a transition between childhood, and adulthood. As Zahran, (2005) points out, adolescence is a "stage of preparation for adulthood". Because this stage accompanied by rapid and critical development changes, adolescents face many psychological, social and academic problems due to physical changes and sexual disorders.

Adolescence is a period of exploration and experimentation that needs adjustment to physical maturity, changing roles within families and with peers, and the emergence of a more independent lifestyle. Compared to adults, adolescents show higher stress levels and fewer coping resources. The stressful process of differentiation and identity consolidation can result in significant psychological

${ }^{(*)}$ Assistant Professor of Educational Psychology, the National Center for Educational Research and Development. .$\wedge 9$. البحثث التتريوي 
distress (Shiferaw, Fantahun, \& Bekele, 2006); (Timmons, \& Margolin, 2015).

At this stage, adolescents face internal psychological conflicts because of their desires, personal interests and the demands of parents, adults, social values and religious beliefs. These conflicts may affect the adolescent's school life and cause many academic problems related to their achievement and continuity in school. Despite the differences in problems that may accompany adolescence, researchers agree on the attendant changes that make this stage receptive and unstable (Sartawi, Duqmaq, \& Abu Helal, 2009).

In this context, Sadeq and Abu Hatab, (1999) pointed out that Stanley Hall (1904) described this stage as "a period of storms, tension, and intensity of psychological crises and suffering, frustration, anxiety and adjusted problems". Zahran, (2005) indicate that there're other problems associated with a lack of achievement, neglect, lack of motivation in school and various social activities, escape from school and other problems of adolescence in school.

Schools all over the world have recently suffered from student problems that seem clearly obvious, whether academic, behavioural, social or emotional, the school administration called for urgently solving them. These problems have become a major barrier in achieving the school's ultimate goal, which is to provide school

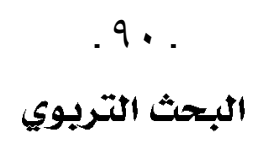




$$
\text { المركن الثومي للبحوث التبويةوالنمية }
$$

environment meet the needs of students (Athanasoula \& Lazaridou, 2008).

Many researchers (e.g., Tannenbaum, 2000; Rayneri, Gerber \& Wiley, 2003; David, 2017) indicated that students' problems in preparatory school can show up as poor academic performance, lack of motivation for school, loss interesting in schoolwork, and poor relationships with peers or teachers.

Many studies focused on academic outcomes and concern academic problems such as low attendance, decreasing academic achievement, and dropping out of school (Benner \& Graham, 2009). There might be several reasons behind these academic problems. Students' connection with the school is one of the main reasons, and studies showed that developing a good connection with the school increases academic success and positive social behaviours. However, when the academic performance and students' school connectedness are decreased, then students may demonstrate some undesirable attitudes such as low attendance to classes (Kocak, 2016).

Badarna (2016) indicated that the literature showed the most common problems among school students are cheating, straying, distraction, lack of concentration, insubordination, hyperactivity, shyness, social withdrawal, aggressive behavior, psychological problems, loss of belonging to the community, rush, neglect of the study, the lack of attention, and low academic achievement.

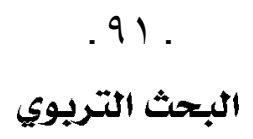


Students are also at increased risk for dropping out of school when they from middle to high school. Students who do not have a good transition are more likely to drop out of school. Low attendance triggers declining grades and lower GPA causes more stressors for students. They may begin to experience more behavioral problems such as anxiety, loneliness, and struggles with academic success (Benner \& Graham, 2009). Excessive sensitivity, a desire to achieve excellence even in unacceptable ways, a weaken level of their mental abilities, and some undesirable behaviours may appear; such as aggression, making noisy, annoying others, procrastination, nontermination of tasks entrusted to them, bad organization, and neglect (Bou Abdullah \& Nani, 2008; Attar, 2012; Al-Qattan, 2016).

In this context, research findings (e.g. Rayneri et al, 2003; Attar, 2012; Qattan, 2016; Kocak, 2016; David, 2017) indicated that the neglect of schools for their students, and the inadequacy of curricula for their needs, dispositions and needs may lead to a failure in satisfying student's mental, cognitive and emotional aspects of personality, and losing enthusiasm and challenge, because of repetitive routines acts required in the classroom. Consequently, the curriculum that does not raise their imagination, recalling their attention and interesting to curiosity, challenge their abilities, lacks them opportunities to express their views, low academic achievement, and educational problems appears.

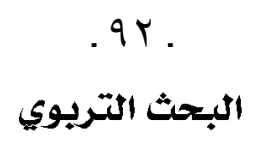




$$
\text { المركن الثومي للبحوث التبويةوالنمية }
$$

Besides, Teenagers face some obstacles from their family, school and community environments that expose their aptitude, skills and abilities to deterioration, and may take a different path that will have a negative impact on the students themselves and their community. In addition, it threatens their psychological comfortability and loses enthusiasm, sense of trust, and responsibility. Also, problems associated with academic achievement and academic compatibility are among the most common problems experienced by students.

Furthermore, students who have attendance problems have decreased participation and low academic performance, and these problems frequently increase the likelihood of dropping out at high school level (Kocak, 2016). Moreover, students suffering from some problems that may lead to bad academic adaptation in their schools (Awandu, 2014). Qattan (2016) showed that the most academic problems which students suffering from it, are those related to insufficiency of educational resources for students, lack of specialized seminars and workshops, and non-organized exploratory scientific trips, As well as increasing student ambition and poor productivity.

Despite the fact that Teenagers have many characteristics, enable them to show aspects of their abilities and skills, in some cases they can't employ these characteristics in educational situations 
and educational achievement due to the presence of many factors that may return to them or to those around them, (Bou abdallah \& Nani, 2008). These problems may be due to students characteristics and personality traits, and it may are a source of anxiety for families and schools, as they may obstruct the implementation of many educational programs offered by schools in order to raise the capacity of students of achievement (Sartawi, Daqmak, \& Abu Helal, 2009).

Because of the unique characteristics students possess, teachers need to be aware of the ways in which these attributes manifest themselves in observable classroom behaviours. Some behaviours can be trouble to the classroom teacher; despite, being aware of their root causes will help teachers more fully meet students' needs and build positive relationships, vital to meaningful classroom experiences (Manning, 2006). Furthermore, Al-Sorour (2010); Elaagez, and Mortaga, (2012) indicated that the problems face student are due to several factors, including the student himself, such as imbalance among his mental, physical, emotional, and social development. Self-accountability, multi interests, boredom and laziness that result from shortening of achievement tests. Hesitation and confusion in facing of the choice of academic and professional, because of mixing affairs and opportunities. Also, it includes the factors related to others, and the external environment, which

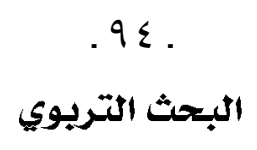




$$
\text { المركن الثومي للبحوث التبويةوالنمية }
$$

including the aspirations of parents, environment inhibitory, evaluation and accounting based on school grades only, and intervention parents in the school performance and selection of academic specialization.

Consequently, teachers should be aware of the causes of educational problems that students face during their study. These problems may lead to dropping out of school, low academic achievement or psychological suffering. Then, providing professional interventions for teachers and others interested in school may help to reduce students' educational problems, who are concerned with the development of educational policies and with the development of curricula that facilitate students' academic life. Furthermore, these professional interventions may help students continue staying in school without tension or anxiety, study their lessons more easily; in addition to, the development and growth of their abilities and skills.

Unfortunately, the topic of school professional practices to reduce educational problems receives little attention by researchers and educators in educational institutions. Hence, the aim of this research was to shed light on the school professional Practices for educational problems, particularly; this topic has often been overlooked or garnered little attention for students in education institutions. 


\section{Research purpose}

The present research deals with school professional practices which proposed to reduce the educational problems, particularly that this topic has often been related for the most students in Preparatory school. More specifically, the present research aimed to investigate the school professional practices that reduce the educational problems from perspective of teachers, and identify the differences in their view according to participants' Gender. For this purpose, answers are sought for the following questions:

1. What are the most important educational problems facing students in Preparatory school?

2. What are the school professional Practices that reduce students' educational problems from teachers' perspective?

3. Are there any differences between views of teachers about the importance of school professional Practices that reduce students' educational problems according to participants' Gender?

\section{Research importance}

The importance of the research seems that it discusses the educational problems faced by preparatory students, that they are in early adolescence stage, and that the associated important developmental changes. Educational institutions in Arab societies






$$
\text { المركن الثومي للبحوث التبويةوالنمية }
$$

suffer from the spread of negative phenomena between students. For example, group cheating phenomena is a big dilemma facing educators, experts, and researchers since decades. The researchers introduced many suggestions to solve this problem, but its' exists until now. The best witness to this, what revealed the results of final exam of the Egyptian General Secondary School in this year. These results revealed that there is a problem related to environmental exam, teachers' and students' values, and school control procedures. The results showed a deviation in degrees towards higher scores of more than $95 \%$ contrary to the moderate distribution for degrees of students on the Jersey curve agreed by the educational psychologists. These results allowed unqualified students to join unappropriate college, while others who are qualified were prevented. Moreover, this entails the enrollment of unqualified persons in important positions in society, and thus leads to delays of this society from other societies in various fields. These negative behaviours lead to students' educational problems in schools which need solutions.

Educational psychologists must intervene to provide a range of radical solutions to these problems that are harmful to future generations.

The importance of current research is determined by:

- Shedding light on some of the educational problems prevalent among Preparatory school students, which result in increasing 
dropout rates and this is a serious problem, because it leads to increasing the social problems in country, especially illiteracy and bad behaviour.

- Providing some of the professional practices that can be done in school, in order to reduce the educational problems facing Preparatory school students.

\section{Research terms}

The current research contains two terms, the first term, "Educational Problems", it means, the case in which the student fails to achieve compatibility between his abilities, skills and different educational situations, because of his personal behaviour or school administration and teachers. The second term, "School professional practices", it means, the behaviours and performances which performed by the school administration, teachers and those interested in school, departments and educational directorates to reduce the problems of school students.

\section{Literature review}

\section{Educational problems}

Literatures mentioned that students face many educational problems during their stay at school. The results of this literature indicate that there are many reasons and factors led to increasing of these problems among Preparatory school students. in particular,

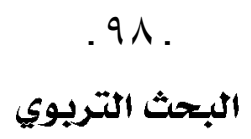




$$
\text { المركن الثومي للبحوث التبويةوالنمية }
$$

including the developmental changes of their adolescence (individual), as well as other family, school and community factors.

According to individual factors, Reis \& McCoach (2000) stated that these factors included personality characteristics in which students are in low self-esteem, low self-concept, low self-efficacy, alienated or withdrawn, distrustful, or pessimistic. Besides, the internal mediators in which students are afraid of failure; they may avoid competition or challenging situations to protect their selfimage or their ability. There is also fear of success, negative attitudes towards school and antisocial or rebellious.

Rimm, (2003) offered some of symptoms that are characterized by students, namely not completing any work assigned to them, not performing homework, not paying attention to the courses, describing the school as boring and useless, and procrastination, and Truancy from school.

Manning, (2006) pointed out that some students may start to become bored and unruly, learn to slow down to avoid more of the same, act out and become disruptive, become non-compliant, hates rote-learning, Irritated by the level of presentation of school work, and dropout either physically or mentally. In addition, Awandu (2014) showed that the problems of learners were related to isolation, lack of motivation. 
Moreover, there are environmental factors as mentioned by Neihart, Reis, Robinson and Moon (2002) that include chronically under challenging, or moving from a regular classroom to an appropriately challenging one, peer pressure to conform to regular norms, to be like everyone else, which may be particularly intense for students from underrepresented minorities, and isolation from classmates and the educational enterprise. In the same context, Awandu study (2014) showed that there was a clear misunderstanding by the teachers of what facilitates learning among learners in secondary schools. The problems were related to inappropriate teaching method, inappropriate curriculum and exploitation and mistreatment.

Rimm, (1987) and Manning, (2006) argue that there are some classroom problem such as unfinished work may be the result of varied interests and inability, poor work habits might also reveal student feelings that he or she already knows about a particular topic and does not feel the need for practice, poor class work is often a sign of disinterest in subject matter, students may question the appropriateness of classroom activities to their needs, students may be ensuring that their work is perfect, students behavioural problems could be a result of boredom or feeling that class work is too easy for them, and emotional outbursts or periods of withdrawal for students may be due to their highly sensitive natures.






$$
\text { المركن القومي للبحوث التبوبةوالتنمية }
$$

In addition, there are extra factors related to family and school in which the attitude that the students have towards school. This may displayed in less care for their schoolwork. Also, parents' high expectations from their children are affect to underachievement (Peters, Willy, Grader-Loidl, Helga, \& Patrica, 2000).

Many researchers (e.g., Tannenbaum, 2000; Rimm, 2003; Bou Abdullah \& Nani, 2008; Attallah, 2008; Al-sorour, 2010; Attar, 2012; El-agiz, \& Mortagie, 2012; Abu Hawash, 2012; Al-Ashoul, 2013; Qattan, 2016) discussed the educational problems and their influences on students' achievement. Findings of these studies revealed many problems that lead to low their academic achievement, and even leaving school, such as, low achievement, lack of concentration, frequency in selection of specialization, neglect of homework and assignments, cheat, loses enthusiasm, truancy, absenteeism, dropout, and avoid responsibility. These problems may face students during stay at school, and lead to the disappearance of their abilities and skills.

\section{School professional practices}

Finning, Harvey, Moore, Ford, Davis, and Waite (2018) point out that the previous research has focused on understanding educational experts' perspectives of causal factors rather than investigating support and intervention strategies that may or may not be helpful in reducing students' educational problems. However,

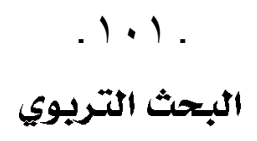


some researchers in the educational field introduced lists of school professional practices to reduce educational problems that face students.

Those researchers listed basic factors of low achievement, or underachievement students. In an attempt to solve such problem, Musungu and Nasongo (2008) investigated a study to identify the instructional role of the head-teacher in academic achievement in Kenya. To improve on supervision of teachers' and students' work the following measures should be adopted:

- Signing of attendance register.

- Spot checks: this is management by walking around.

- Moving while lessons are going on would enable head teachers to monitor teaching.

- Regular inspection of lesson notes, schemes of work and attendance registers.

- Random inspection of pupils' books and assignments.

In another attempt, Karaduman (2013) stated some School professional practices that can be performed by school administration, and teachers for reducing underachievement in students. These practices include:

- Preparing and applying long lasting guidance programs and consultancy.

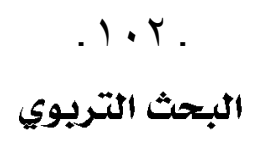




$$
\text { المركن الثومي للبحوث التبويةوالنمية }
$$

- Telling both student and his/her family what they need to do for achievement and help them to understand the reality.

- Finding the resources that make them underachievement, and have to solve problem and take cautions working with student and family cooperatively.

- Communication between students and teachers.

- Interviewing with teachers to solve the problem.

- Communicating with the teacher about the underachiever.

- Helping the underachiever listen effectively in class and ask effective questions.

- Helping the underachiever remedy skill deficits.

- Participating constructively in the underachiever's life at school.

Cheating is a big problem encountered by students. Academic cheating has become a serious problem at schools and colleges. Cheating means copying from other students during exams, one of the forms of misconduct that has become one of the biggest concerns of educational institutions (Wilkinson, 2009). And academic cheating is defined by Dahiya (2015) as a representing someone else's work as your own, It can take many forms, including sharing another's work, purchase a tests (exams) in advance, paying another to do the work for you. 
Dahiya (2015) revealed that the best approach to preventing cheating may be to appeal to student's higher morals since values seem to be so important, rather than simply trying to catch cheaters. Concerning the school atmosphere, they all play a role in an student's life. Academic dishonesty occurs every day and there are driving forces behind why one chooses academic dishonesty over academic integrity. The promotion of academic integrity and mastery goals appears to serve as a significant factor for prevention of academic dishonesty. Through promoting integrity, mastery goals and individual interventions, a decline in academic cheating would be expected.

Similarly, in Diego's (2017) study, some recommendations were included related to teacher's professional practices to reduce the problem of cheating, such as:

1. Educators should use positive reinforcement and encouraging the students to acquire a positive outlook in life that will prevent them from cheating.

2. Teachers can reduce the tendency to cheat by involving students in interesting assignments that are more engaging and relevant to the students themselves.

3. Teachers should aim for a "zero tolerance" approach with regard to cheating and plagiarism in their academic environment. In

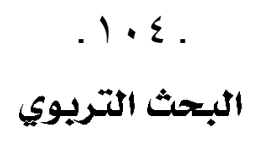




$$
\text { المركن الثومي للبحوث التبويةوالنمية }
$$

order to reach the so-called zero tolerance towards cheating during examinations.

4. Teachers should make clear the acceptable and unacceptable behaviour of the students at the very beginning of the year, stick to it as far as possible, and frequently remind the students of it.

5. Subject teachers should also make sure their students correctly understand the terms and conditions of the subject by discussing them in class if necessary.

6. Teachers should make it clear to students that resisting temptation to cheat during examinations boosts and builds high self-esteem, self-respect, and told them that students with higher levels of self-confidence were less likely to engage in academic misconduct.

Lack of concentration is another problem face students. Concentration is centering the mind on one single thought, a student concentrates on the material he is required to study, and teacher concentrate on the learning of subject he has to teach. It means that, everybody possesses ability to concentrate. Therefore, concentration is thus a great necessity for all people (Grewal, 2014).

Training and Technical Assistance Center (2017) stated many interventions to prevent that problem and increase students' attention. These interventions included peer tutoring, cooperative learning, 
sharing strategies (think, pair, share/square share/group share, partner reading, self-correction opportunities, learning games and studentcreated reviews). Besides seating arrangements are very important which included: Seat the student away from distractions and close to the teaching action, place the student in close proximity to instruction so the teacher can monitor the student's work, place the student by peers who are attentive workers, and make space between student desks.

Grewal, (2014) also revealed that somebody need to learn and practice concentration strategies, it is involve (1) learning mental self-regulation and (2) arranging factors that can control. Moreover, improving concentration is a skill may be learn, and learning a skill may need to practice; whether it is typing, writing, or concentrating in a classroom.

Moreover, the educational problem faced by students is truancy that affects students' success in school that can have a longterm effect on the students. Students' truancy from school is a common problem encountered by the school teachers and other professionals who work in the field of education. As a general descriptive term, truancy is used to refer to students who are absent from school for any reason without their parents' knowledge (Kearney, 2008). Truancy is typically defined as a certain number of unexcused absences.

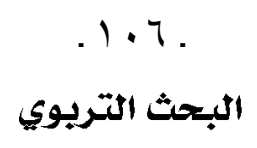




$$
\text { المركن الثومي للبحوث التبويةوالنمية }
$$

Trujillo (2006) study asked ten questions about what principals believed were the most effective strategies for reducing truancy. The results of the study indicated that number one on principals' list, with $72 \%$, was the provision of additional professional development to teachers. However, school climate, attachment to teachers, and feelings of physical safety, has been shown greatly to affect a student's desire to attend school. Besides, Vicki (2008) conducted a study on truancy at 59 high schools in the Minneapolis region to find out variables that are related to school attendance rates. Results showed that school attendance increased when there is an excessive attendance policy in which learners loses marks after to a particular number of class absences.

Reimer and Dimock (2005) identified several critical components for effective truancy prevention programs: broad-based multidisciplinary collaboration of community agencies such as schools and social services, family involvement, comprehensive approach that addresses all of the factors that affect truancy, combine meaningful sanctions for truancy and appropriate incentives for attendance to promote pro-school attitudes and change the behaviour of students, and create a supportive context for learning that includes organizations, community cultures, and policies.

Maynard, McCrea, Pigott, and Kelly (2013) conducted a meta-analysis that examined interventions aimed to increase school $.1 \cdot V$. 
attendance for students who were identified as having chronic attendance problems. Results showed students who received the various indicated truancy interventions did better than those that did not on attendance outcomes. This meta-analysis study also found that the lack of evidence to support the general belief that collaborative and multimodal interventions are more effective than simple, noncollaborative interventions. These findings are encouraging in that various types of programs can be just as effective in helping chronically absent students.

In the same way, Hanover Research (2016) examined research-based strategies for addressing absenteeism and truancy in middle and high schools. This included:

- Understanding the causes and effects of truancy has critical implications for the design of strategies and programs meant to target student attendance.

- A comprehensive, collaborative approach between School districts, schools, and families is necessary for effectively targeting truancy at the secondary level, and provide positive reinforcement for attendance and timely consequences for nonattendance, and track student data consistently.

- Individual support strategies can help promote school attendance and foster school engagement.






$$
\text { المركن الثومي للبحوث التبويةوالنمية }
$$

- Small Learning Communities offer a more flexible, personalized, and responsive environment that contribute to increased student attendance and academic success.

- Teachers can promote active learning by fostering a sense of competence in students, embracing collaborative learning opportunities, and establishing positive teacher-student relationships.

On the other hand, absenteeism is another educational problem. It is not the same thing as truancy. Students who absent from school are at risk for dropping out of school early, resulting in the long-term effect of becoming unemployed, falling into the poverty trap, and engaging in various act of misbehaviour. According to Balfanz and Byrnes, (2012) absenteeism means missing $10 \%$ of the school year for any reason. Again, the threshold number or percentage can vary from school to school. Cumbo, Burden and Burke, (2012) stated that middle and secondary schools could implement some of the following policies to recapture students and encourage student engagement, which ultimately contributes to reduce student absenteeism.

1. Award partial credit for completed course work. Although grading based on attendance feels like a good way to reward students for participating in class, failing a student after a set number of absences is not an appropriate punishment.




2. Eliminate automatic withdrawal due to excessive absences, it is common for schools to withdraw and dis-enrol students due to unexcused absences without any intervention. Overcrowding, limited school supplies and high teacher-student ratios may lead schools to let go of absent students.

3. Using suspensions or expulsions to punish students for excessive absences is counterproductive; this practice does not increase school engagement or prevent future absences.

4. Using community service is good alternative to increase school engagement or prevent future absences.

5. Participation in extracurricular activities and field trips should be used as incentives not punishments.

Kim, and Streeter (2016) identified some interventions or strategies to solve absenteeism problem which were related to:

1. School social workers and other counsellors assess reasons a student is absent, focusing on school- and family-related issue.

2. School social workers and other counsellors communicate with families when students are absent.

3. School social workers and other counsellors hold workshops for parents, and visit the home.

4. Involving referring students to school social workers and/or truant officers.

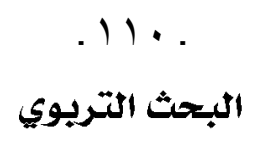




$$
\text { المركن الثومي للبحوث التبويةوالنمية }
$$

5. Providing attendance awards can also be helpful, but they should be given as incentives for improved attendance and not just for perfect attendance.

6. Implement after-school programs that motivate students to attend school in order to support their participate, improving student selfesteem and building social skills.

Finally, Kevin and Knoster (2016) stated some interventions for addressing student absenteeism which include: promoting consistent and regular attendance for all students, identifying and initiating individualized interventions with students at risk of falling into patterns of chronic absenteeism, and conducting comprehensive and intense interventions for students whom engaging in chronic absenteeism.

Moreover, dropout is another educational problem which leads to failure in school. A student dropout is described as "someone who did not complete the school program due to achieving below determined potential or achieving according to potential" (Hartman, 2016).

Dropped out due to other reasons, Chirtes (2010) stated the factors cause dropout which include:

a) Family-related factors such as lack of interest, separation, divorce, parents' detention, conflicts, hostile environment, 
parents forcing children to work, parents' death, and parents' inability to raise children.

b) Personal factors such as attention deficiency disorder, memory deficiency, visually impaired, low learning abilities, misbehaviour, and low motivation and lack of interest.

c) School Environment such as school adjustment failure, not promoting school, discipline problems, school phobia, school violence, and conflicts (with teachers, school mates).

Hartman (2016) investigated a study to identify which environmental, personal, and demographical factors contribute to students' dropout behaviour. Based on the results, the intelligence and the motivational components are not good predictors of dropout behaviour of students, whereas school' location and climate seems to have influence on dropping out. The results recommended overcoming dropout by increase students' intrinsic motivation through giving assignments that are new, challenging, and interesting for the students, and by offering choices in their own learning. Besides, results recommended for teachers to include task managing and preparing into the daily curriculum, to help students in carrying out executive functions.

In an attempt to solve such problem, Renzulli, and Park (2002) suggested ten strategies to help school members in dropout prevention: (a) alter the instructional environment, (b) establish

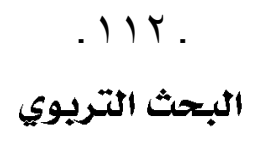




$$
\text { المركن الثومي للبحوث التبويةوالنمية }
$$

effective school membership, (c) develop career academics, (d) develop appropriate and supportive school board policies, (e) determine the students' learning styles, (f) consider community-based collaboration, $(\mathrm{g})$ establish a case management intervention system, (h) create a mentoring network, (i) establish a school within a school, and (j) use state-legislated negative-sanction policies.

There are a several suggestions interventions should be considered in a prevention program, such as: First, as early as possible, schools leaders and teachers need to identify students who are at risk of dropping out of school. Second, schools should provide an appropriate curriculum that addresses students' needs, interests, and learning styles. Third, more opportunities for extracurricular activities and encouragement to participate in them should be provided to the students who are at risk of dropping out. Fourth, student and teacher relationships should be improved, because previous research point out that negative attitude toward school and teachers is a major contributor to dropping out. Fifth, counselling services and special programs should be given to students who fail school, because of personal or school-related problems, who have psychological problems, and who must work to support their family. Sixth, schools should communicate closely with parents whose student has the potential to drop out of school, and parents should have more involvement with regard to their child's problems. 
Seventh, schools should develop links with the community and work with organizations that can provide appropriate services (Renzulli \& Park, 2002).

In addition, the results of Dockery's (2012) study suggested the following dropout prevention Interventions:

1) Academic Interventions: Tutoring, academic support, afterschool programming, service learning, accelerated credit accumulation and extra classes.

2) Psychosocial Support: Behavioural interventions, structured extracurricular activities, life skills development, counselling, anger management, conflict resolution and addressing transitions.

3) Family Interventions: Engaging, strengthening and/or counselling with families.

4) Targeting High Risk Behaviours Probation: Monitoring truancy and attendance, teen parenting, substance abuse prevention/intervention.

5) Adult Support Mentoring: Case management, court advocates, service coordination.

6) School Structure and Programming: School environment, classroom climate, school reorganization, freshmen academies, professional development, systemic/policy renewal.

7) School Curriculum: Differentiated teaching, student-focused instruction, interactive instruction, culturally or linguistically






$$
\text { المركن الثومي للبحوث التبويةوالنمية }
$$

relevant instruction, high academic standards and rigorous curriculum for all students, link to career development, job training and workforce readiness.

Finally, most previous studies have provided some school professional practices that can reduce the educational problems of school' students in general. Therefore, the researcher conducted a pilot study in which he tried to identify the most important problems facing Preparatory stage students from the point of view of teachers.

\section{Pilot study}

The researcher reviewed the above literature that related to educational problems, collected the most important ten problems, and put them in checklist, chose twenty experts teachers randomly from two preparatory schools in Cairo and Dakahlia governorates. And asked them to arrange and determine the educational problems that are more important, and need to reduce than others from the checklist that contains ten problems: 1) Low achievement, 2) Lack of concentration, 3) frequency in selection of specialization, 4) neglect of homework and assignments, 5) Cheat, 6) loses enthusiasm, 7) Truancy, 8) Absenteeism, 9) Dropout, and 10) avoid responsibility.

Participants' (twenty experts teachers) arranged the problems in checklist according to its importance, and pointed out that there are important six problems' require more interested from school 
community members, and need to professional interventions for reducing and resolving. This six problems are, "Low achievement (LA), Cheat (C), Lack of concentration (LC), Truancy (T), Absenteeism (A), and Dropout (D)". And so on, the first research question has been answered.

\section{Methodology}

The explanatory descriptive method was used to identify the most important school professional practices and the differences between participants, as well as the relationship between these practices in the light of some variables, and their importance in to reduce students' educational problems.

\section{Participants}

Participants were randomly selected of (150) participants, only (146) participants who completed the Questionnaire, which included (81) females, and (65) males in the preparatory schools from three governorates: Cairo, Dakahlia, and Sharkia, to conduct the field study. Participants who did not complete the answer were excluded.

Table 1: The Frequency for governorates and gender of study field application

$$
\begin{aligned}
& \text { governorates male }{ }^{\text {gender }} \text { female } \\
& \begin{array}{llllll}
\text { Freq. } & \begin{array}{l}
\text { Per. } \\
(\%)
\end{array}
\end{array} \quad \text { Freq. } \begin{array}{l}
\text { Per. } \\
(\%)
\end{array} \text { Freq. } \begin{array}{r}
\text { Per. } \\
(\%)
\end{array} \\
& \begin{array}{lllllll}
\text { Cairo } & 47 & 32.2 & 16 & 34.1 & 31 & 65.9
\end{array} \\
& .117 . \\
& \text { البـحث التربوي }
\end{aligned}
$$




$$
\text { المركن الثومي للبحوث التبويةوالنمية }
$$

\begin{tabular}{ccccccc}
\hline \hline & & & & & & \\
& & $\%$ & & $\%$ & & $\%$ \\
Dakahlia & 50 & 34.2 & 26 & 52.0 & 24 & 48.0 \\
& & $\%$ & & $\%$ & & $\%$ \\
sharkia & 49 & 33.6 & 23 & 47.0 & 26 & 53.0 \\
& & $\%$ & & $\%$ & & $\%$ \\
Total & 146 & 100.0 & 65 & 44.5 & 81 & 55.5 \\
& & $\%$ & & $\%$ & & $\%$
\end{tabular}

\section{Instrument}

The researcher chose the first six problems that Participants' arranged it in checklist according to its importance, and need to professional interventions for reducing and resolving, such, "Low achievement (LA), Cheat (C), Lack of concentration (LC), Truancy (T), Absenteeism (A), and Dropout (D)". The researcher collected and created some school professional practices that may reduce six problems, discuss its' with some educational experts, and educational experts introduced advices and suggestions for modifications. Initial version of the school professional practices Questionnaire (SPPQ) is a 50-items self-administered questionnaire designed to measure the school professional practices from the teachers' perspective.

The Questionnaire composed of six subscales including, Low achievement (LA), Cheating (C), Lack of concentration (LC), Truancy (T), Absenteeism (A), and Dropout (D), Responses are made on a 4-point Likert scale (4 totally agree, 3 agree, 2 disagree, 1 
totally disagree). The psychometric properties of the SPPQ has been found a good structural validity, internal consistency, and reliability:

\section{Structural validity}

The participants' responses were analysed (50) participants on the (50) items covers separated six subscales for the confirmatory factor analysis by the structural equation modeling and Maximum Likelihood method. In addition, Data has shown six distinct factors, in the following table:

Table (2) items loadings on 6 subscales for the School professional practices' questionnaire $(n=50)^{(*)}$

\begin{tabular}{|c|c|c|c|c|c|c|c|c|c|c|c|c|c|c|}
\hline \multicolumn{5}{|c|}{ Low achievement (LA) } & \multicolumn{5}{|c|}{ Cheating (C) } & \multicolumn{5}{|c|}{ Lack of concentration (LC) } \\
\hline $\mathbf{N}$ & $\begin{array}{l}\text { SR } \\
\text { W }\end{array}$ & $\mathbf{R W}$ & S.E. & C.R. & $\mathbf{N}$ & $\begin{array}{l}\text { SR } \\
\text { W }\end{array}$ & RW & S.E. & C.R. & $\mathbf{N}$ & $\begin{array}{l}\text { SR } \\
\text { W }\end{array}$ & RW & S.E. & C.R. \\
\hline 1 & .35 & 1.00 & & & 12 & .62 & 1.00 & & & 20 & .41 & 1.00 & & \\
\hline 2 & .74 & 1.28 & .55 & $2.34 *$ & 13 & .71 & 1.20 & .34 & $3.50 * *$ & 21 & .61 & 1.66 & .55 & $2.99 * *$ \\
\hline 3 & .47 & 1.10 & .55 & $2.01 *$ & 14 & .58 & .99 & .32 & $3.11 * *$ & 22 & .82 & 2.17 & .81 & $2.67 * *$ \\
\hline 4 & .59 & 1.60 & .64 & $2.52 *$ & 15 & .57 & .91 & .29 & $3.19 * *$ & 23 & .54 & 1.86 & .77 & $2.41 *$ \\
\hline 5 & .81 & 1.80 & .76 & $2.38^{*}$ & 16 & .56 & .83 & .27 & 3.04*** & 24 & .51 & 1.21 & .41 & $2.94 * *$ \\
\hline 6 & .67 & 1.12 & .49 & $2.28 *$ & 17 & .48 & .80 & .29 & $2.71^{* * *}$ & 25 & .49 & 1.33 & .62 & $2.51 *$ \\
\hline 7 & .65 & 1.14 & .46 & $2.50 *$ & 18 & .71 & 1.14 & .39 & $2.89 * *$ & 26 & .58 & 1.38 & .62 & $2.22 *$ \\
\hline 8 & .68 & 1.69 & .74 & $2.29 *$ & 19 & .28 & .50 & .29 & 1.72 & 27 & .51 & 1.29 & .57 & 2.28 * \\
\hline 9 & .59 & .82 & .37 & $2.20 *$ & & & & & & & & & & \\
\hline 10 & .45 & .91 & .37 & $2.47^{*}$ & & & & & & & & & & \\
\hline 11 & .45 & 1.21 & .61 & $2.00^{*}$ & & & & & & & & & & \\
\hline
\end{tabular}

(*) Note; Number of item (N), Standardized Regression Weights (SRW), Regression Weights (RW), Standard error (S.E.), and Critical Ratio (C.R.). Critical Ratio Value is significant at: $(*) p<0.05$. and $(* *) p<0.01$

$$
\text { البحث التريوي } 11 \text {. }
$$





From the previous table, six models were derived from the participants' responses to the school professional practices Questionnaire. These models (the school professional practices for reducing problems) are: the first latent variable "school professional practices for reducing low achievement (LA) problem": it contains 11 items, all items are significances, and are loaded under this factor. Second latent variable "school professional practices for reducing cheat (C) problem": it contains 8 items, and only 7 items were loaded under this factor, except one item. Third latent variable "school professional practices for reducing lack of concentration (LC) problem": it contains 8 items, and all items are loaded under this factor. Fourth latent variable "school professional practices for reducing truancy $(\mathrm{T})$ problem": it contains 7 items, and all items were loaded under this factor. Fifth latent variable "school professional practices for reducing absenteeism (A) problem": it contains 7 items, and only 6 items are loaded under this factor, except one item. And, sixth latent variable "school professional practices for reducing dropout (D) problem": it contains 9 items, and only 8 items are loaded under this factor, except one item. The six model provided a better fit to the data from the participants' 
responses to the school professional practices Questionnaire, and the next table show these results:

Table (3) Goodness Fit Indices for the subscales of

School professional practices' questionnaire $(n=50)$

\begin{tabular}{|c|c|c|c|c|c|c|}
\hline \multirow[b]{2}{*}{ indicators } & \multicolumn{6}{|c|}{ Latent variables } \\
\hline & $\begin{array}{c}\text { Low } \\
\text { achievement } \\
\text { (LA) }\end{array}$ & $\begin{array}{c}\text { Cheating } \\
\text { (C) }\end{array}$ & $\begin{array}{c}\text { Lack of } \\
\text { concentration } \\
\text { (LC) }\end{array}$ & $\begin{array}{c}\text { Truancy } \\
\text { (T) }\end{array}$ & $\begin{array}{l}\text { Absenteeism } \\
\text { (A) }\end{array}$ & $\begin{array}{l}\text { Dropout } \\
\text { (D) }\end{array}$ \\
\hline Chi2 & 28.171 & 22.487 & 9.118 & 11.495 & 9.523 & 15.932 \\
\hline DF & 33 & 18 & 13 & 10 & 11 & 23 \\
\hline $\mathbf{P}$ & .706 & .211 & .764 & .320 & .574 & .858 \\
\hline CMIN/DF & .854 & 1.249 & .701 & 1.150 & .866 & .693 \\
\hline GFI & .912 & .906 & .955 & .931 & .952 & .936 \\
\hline AGFI & .823 & .811 & .877 & .807 & .878 & .875 \\
\hline CFI & 1.000 & .945 & 1.000 & .983 & 1.000 & 1.000 \\
\hline RMSEA & .000 & .071 & .000 & .055 & .000 & .000 \\
\hline RMR & .034 & .024 & .017 & .024 & .015 & .016 \\
\hline $\mathbf{I C}$ & 94.171/ & $58.487 /$ & $55.118 /$ & 47.495/ & 43.523/ & $59.932 /$ \\
\hline AIC & 132.000 & 72.000 & 72.000 & 56.000 & 56.000 & 90.000 \\
\hline CAIC & $190.268 /$ & $110.904 /$ & $122.095 /$ & 99.912/ & 93.027/ & 123.997/ \\
\hline CAIC & 324.194 & 176.833 & 176.833 & $\mathbf{1 3 7 . 5 3 7}$ & $\mathbf{1 3 7 . 5 3 7}$ & 221.041 \\
\hline FCVI & $1.922 /$ & $1.194 /$ & $1.125 /$ & $.969 /$ & $.888 /$ & $1.223 /$ \\
\hline ECVI & 2.694 & 1.469 & 1.469 & 1.143 & 1.143 & 1.837 \\
\hline
\end{tabular}

The above indicators show Goodness of Fit for models that generated from Confirmatory factor analysis (CFA), it means that, the questionnaire have a good structural validity, and becomes (47) items.

\section{Internal consistency}

The results of statistical treatments for data showed that the questionnaire was consistent with the internal consistency between its (47) distinct items after deleting (3) non-distinct by conducting structural validity. The correlation coefficients between the total score of subscales and its items are as follows table:

Table (4) correlation coefficients between six subscales for School professional practices' questionnaire and its items $(n=50)$

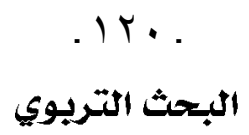




$$
\text { المركن الثومي للبحوث التبويةوالنمية }
$$

$\begin{array}{cccccccccc}\text { NO } & \mathbf{R}^{(*)} & \text { NO } & \mathbf{R} & \text { NO } & \mathbf{R} & \text { NO } & \mathbf{R} & \text { NO } & \mathbf{R} \\ 1-1 & .60 & \mathbf{1 - 1 1} & .63 & \mathbf{3 - 2 2} & .72 & \mathbf{4 - 3 1} & .74 & \mathbf{5 - 4 1} & .68 \\ \mathbf{1 - 2} & .61 & \mathbf{2 - 1 2} & .63 & \mathbf{3 - 2 3} & .62 & \mathbf{4 - 3 2} & .76 & \mathbf{6 - 4 2} & .76 \\ \mathbf{1 - 3} & .69 & \mathbf{2 - 1 3} & .75 & \mathbf{3 - 2 4} & .62 & \mathbf{4 - 3 3} & .64 & \mathbf{6 - 4 3} & .70 \\ 1-4 & .71 & \mathbf{2 - 1 4} & .66 & \mathbf{3 - 2 5} & .58 & \mathbf{4 - 3 4} & .75 & \mathbf{6 - 4 4} & .70 \\ 1-5 & .78 & \mathbf{2 - 1 5} & .69 & \mathbf{3 - 2 6} & .57 & \mathbf{5 - 3 5} & .69 & \mathbf{6 - 4 5} & .63 \\ 1-6 & .67 & \mathbf{2 - 1 6} & .61 & \mathbf{3 - 2 7} & .70 & \mathbf{5 - 3 6} & .71 & \mathbf{6 - 4 6} & .51 \\ 1-7 & .62 & \mathbf{2 - 1 7} & .60 & \mathbf{4 - 2 8} & .62 & \mathbf{5 - 3 8} & .69 & \mathbf{6 - 4 7} & .71 \\ 1-8 & .67 & \mathbf{2 - 1 8} & .68 & \mathbf{4 - 2 9} & .63 & \mathbf{5 - 3 9} & .74 & \mathbf{6 - 4 8} & .68 \\ 1-9 & .50 & \mathbf{3 - 2 0} & .60 & \mathbf{4 - 3 0} & .51 & \mathbf{5 - 4 0} & .70 & \mathbf{6 - 4 9} & .72 \\ 1-10 & .60 & \mathbf{3 - 2 1} & .69 & & & & & & \end{array}$

(*) (All correlations are significances $\mathbf{p}<\mathbf{0 . 0 1})$

The internal consistency results shown that all correlation coefficients between the total score of subscales and its items are significant at the 0.01. Consequently, the questionnaire becomes (47) items, and have good internal consistency.

\section{Reliability}

The reliability coefficient of six subscales which compose the questionnaire in this research is estimated by Cronbach's alpha, the values of reliability coefficient if item deleted are ranged between 0.73 and 0.85 for all 47 items, all of which are statistically acceptable values indicating that the subscales included in the questionnaire be reliable. And subscales reliability respectively are: $(0.85,0.78,0.79$, $0.78,0.79,0.82)$. Consequently, the questionnaire have good reliability.

\section{Procedures}


- The researcher review literature related to the variables of research, collected the most important ten problems, and put them in checklist.

- Asked twenty teachers from the preparatory schools to arrange the educational problems that are more important and need to reduce than others from the checklist.

- Participants' arranged the problems in checklist according to its importance from their prospective.

- The researcher collected and created some school professional practices, discuss them with educational experts, and they introduced suggestions for modifications

- The researcher prepared the initial setup of the school professional practices Questionnaire (SPPQ).

- To identify and calculate the psychometric properties of the (SPPQ), it was applied to (50) teachers, (males and females).

- According to the results of psychometric properties, the final image of the research instrument was prepared.

- Participants answered the final image of the school professional practices Questionnaire items.

- Finally, Data entry and processing of appropriate statistical treatments to answer the research questions, and Preparation of data tables and interpretation of the results in light of theoretical framework and previous studies.

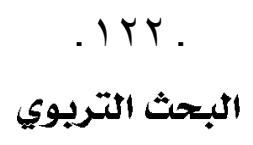




$$
\text { المركن القومي للبحوث التبوبةوالنمية }
$$

\section{Data Collection Time}

The application of research instrument was conducted on the participants, and Data were collected during the second semester of the academic year 2018/2019.

\section{Statistical Analysis}

Data collected were analysed by using the statistical package program SPSS 23.0. Data analysis techniques were performed by using descriptive statistics, to calculate the statistical treatments for the results of the research.

\section{Results}

The data collected were tabulated accordingly for computation of Descriptive Statistics (Means and Std. Deviation) to help in finding out the impact of participants' demographic variable (gender) on the school professional practices for reducing students' educational problems. Besides, the professional practices that are important from the view of the participants. The accepted views in this study are those that exceed their mean scores up to 3.00, because almost participants are argue the importance of all the professional practices.

The following tables show mean scores and std. deviation for six subscales of school professional practices for reducing students' educational problems by which the questionnaire was composed of:

Table (5) Descriptive Statistics for the school professional practices to reduce the first problem "Low achievement (LA)"

Items

\section{Creating additional} strengthening groups for students participating in post-school activities

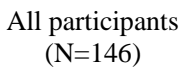

M St.D

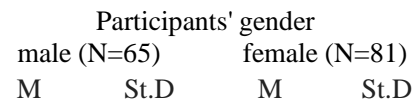

$3.28 \quad .81$ 
2. Putting the curriculum on the school website

$\begin{array}{llllll}3.59 & .64 & 3.52 & .69 & 3.64 & .60\end{array}$

3. Teacher using various activities in explaining syllabus

4. Making content summaries for students

$\begin{array}{llllll}3.46 & .68 & 3.32 & .66 & 3.57 & .67\end{array}$

$\begin{array}{llllll}3.09 & .90 & 2.95 & 1.04 & 3.20 & .77\end{array}$

5. Giving content CDs to students

$\begin{array}{llllll}3.35 & .75 & 3.42 & .73 & 3.30 & .77\end{array}$

6. Holding meetings with students to follow up their academic status

$\begin{array}{llllll}3.52 & .60 & 3.51 & .56 & 3.53 & .63\end{array}$

7. Organizing students' groups to share their ideas on content

$\begin{array}{llllll}3.51 & .55 & 3.52 & .53 & 3.49 & .57\end{array}$

$\begin{array}{llllll}3.33 & .73 & 3.32 & .66 & 3.33 & .78\end{array}$
textbook references

9. Using modern tools of teaching such as smart boards

$\begin{array}{llllll}3.68 & .56 & 3.69 & .56 & 3.68 & .57\end{array}$

10. Providing students with simplified explanations of some topics of the

$\begin{array}{llllll}3.45 & .69 & 3.29 & .72 & 3.58 & .63\end{array}$

curriculum by educational experts

11. equipment classrooms and creation school climate to be attractive to attention

$\begin{array}{llllll}3.16 & .79 & 3.11 & .81 & 3.20 & .78\end{array}$

Table 4 presents descriptive statistics for the school professional practices for reducing students' low achievement (LA) problem.

From all participants' view, the mean and standard deviation scores show that there were important school professional practices to reduce students' low achievement (LA), such as, "using modern tools of teaching such as smart board, Putting the course content on

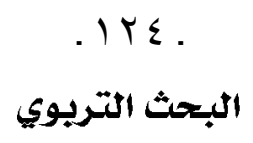




$$
\text { المركن القومي للبحوثالنبوبةوالنمية }
$$

the school website, and Holding meetings with students to follow up their academic status", $(\mathrm{M}=3.68,3.59 \& 3.52$ respectively). On the other hand, the results show less important school professional practices such as, "equipment classrooms and creation school climate to be attractive to attention, and creating additional strengthening groups for students participating in post-school activities" $(\mathrm{M}=3.16$ \& 3.28 respectively).

According to gender, the mean and standard deviation' results revealed a near unanimity among both male and female for the importance of all professional practices, males (M. ranges from 2.95, to 3.69), and females (M. ranges from 3.20, to 3.68). All participants' points out that all professional practices are important, such as, "using modern tools of teaching such as smart board", and "putting the course content on the school website". In addition, the importance of practice "organizing students' groups to share their ideas on content", was felt by males, but females argue the importance "providing students with simplified explanations of some topics of the curriculum by educational experts". In contrast, they agreed among themselves that the two professional practices "making content summaries for students," and "equipment classrooms and creation school climate to be attractive to attention", were less important to reduce this problem.

Table (6) Descriptive Statistics for the school professional practices to reduce the second problem "Cheating $(C)$ " 


\section{Items}
All participants $(\mathrm{N}=146)$

Participants' gender

male $(\mathrm{N}=65) \quad$ female $(\mathrm{N}=81)$

$\begin{array}{llll}M & \text { St.D } & \text { M }\end{array}$

12. Using a variety of assessment methods not just the achievement test

$\begin{array}{llllll}3.34 & .62 & 3.34 & .64 & 3.35 & .60\end{array}$

13. Diversifying test questions so that they are not limited to memorizing questions

14. Using computerise tests in monthly assessment of students achievement

$\begin{array}{llllll}3.57 & .56 & 3.52 & .62 & 3.60 & .52\end{array}$

$\begin{array}{llllll}3.45 & .61 & 3.51 & .59 & 3.40 & .63\end{array}$

15. Conducting regular tests to accustom the student to tests

16. Holding seminars on the impact of cheating on the individual and society

$\begin{array}{llllll}3.52 & .55 & 3.57 & .56 & 3.48 & .55\end{array}$

$\begin{array}{llllll}3.62 & .50 & 3.54 & .53 & 3.69 & .47\end{array}$

17. Setting up many test forms for monthly and final exams



18. Creating a good climate

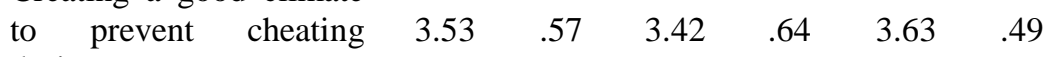
during tests

Table 6 presents descriptive statistics for the school professional practices for reducing students' cheat (C) problem. From all participants' perspective, the mean and standard deviation scores show that there were important school professional practices to reduce students' cheat may be important, such as, "holding seminars on the impact of cheating on the individual and society, diversifying test questions so that they are not limit to memorizing questions, and creating a good climate to prevent cheating during tests" $(M=3.62$, $3.57 \& 3.53$ respectively). On the other hand, the results show less

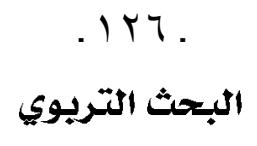




$$
\text { المركن الثومي للبحوث التبويةوالنمية }
$$

important school professional practices such as, "setting up many test forms for monthly and final exams", and "using a variety of assessment methods not just the achievement test" $(\mathrm{M}=3.31 \& 3.34$ respectively).

According to gender, the mean and standard deviation' results revealed a near unanimity among both male and female for the importance of all professional practices, males (M. ranges from 3.25, to 3.57), and females (M. ranges from 3.35, to 3.69). While male point out that important professional practices are, conducting regular tests to accustom the student to tests, and holding seminars on the impact of cheating on the individual and society, female point out, holding seminars on the impact of cheating on the individual and society, and creating a good climate to prevent cheating during tests.

In contrast, all participants revealed that using a variety of assessment methods not just the achievement test, and setting up many test forms for monthly and final exams as a professional practices seems less important to reduce this problem.

Table (7) Descriptive Statistics for the school professional practices to reduce the third problem "lack of concentration $(L C)$ "

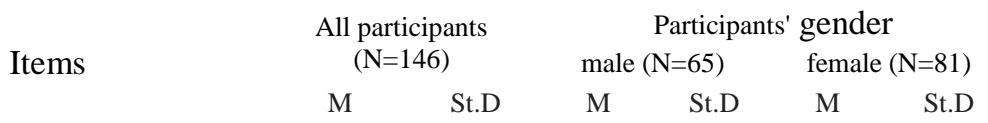

19. Providing

opportunities for participation of $\begin{array}{llllll}3.51 & .54 & 3.49 & .50 & 3.53 & .57\end{array}$ students in explaining

$$
\begin{aligned}
& . I T V . \\
& \text { البحثث التريوي }
\end{aligned}
$$


the subject of the

session

20. Using solving

problems strategy in

explaining subjects by

$\begin{array}{llllll}3.45 & .53 & 3.49 & .56 & 3.41 & .49\end{array}$

teachers

21. Using teaching groups method to ensure all students' participation

$\begin{array}{llllll}3.46 & .61 & 3.52 & .66 & 3.41 & .57\end{array}$

22. Asking sudden questions to students during the session

$\begin{array}{llllll}3.26 & .73 & 3.35 & .80 & 3.19 & .67\end{array}$

23. Holding a meeting between the social worker or the psychologist with the

$\begin{array}{llllll}3.56 & .50 & 3.57 & .50 & 3.56 & .50\end{array}$
student to solve his/her problem

24. Performing medical examinations for students to make sure that they are free from

$\begin{array}{llllll}3.46 & .61 & 3.45 & .59 & 3.47 & .63\end{array}$
the diseases that led to problems

25. Engaging students in enrichment activities relevant to their

$\begin{array}{llllll}3.60 & .53 & 3.68 & .47 & 3.54 & .57\end{array}$
hobbies

26. Conducting psychological tests for students to make sure they are free from any psychological disorder

$\begin{array}{llllll}3.39 & .65 & 3.45 & .66 & 3.35 & .64\end{array}$

Table 7 presents descriptive statistics for the school professional practices for reducing students' lack of concentration (LC) problem. From all participants' perspective, the mean and standard deviation scores shows that all professional practices to reduce students' lack of concentration may be important, such as:

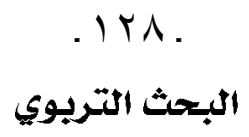




$$
\text { المركن الثومي للبحوث التبويةوالنمية }
$$

"engaging students in enrichment activities relevant to their hobbies", "holding a meeting between the social worker or the psychologist with the student to solve his/her problem", and "providing opportunities for participation of students in explaining the subject of the session", $(\mathrm{M}=3.60,3.56 \& 3.51$ respectively $)$. On the other hand, the results show less important school professional practices to reduce students' lack of concentration problem asking sudden questions to students during the session, $(\mathrm{M}=3.26$ respectively).

According to gender, the mean and standard deviation' results revealed a near unanimity among both male and female for the importance of all professional practices, males (M. ranges from 3.35, to 3.68), and females (M. ranges from 3.19, to 3.56). At the same time, participants argue that all school professional practices are important to reduce the lack of concentration problem for students. They points out that important professional practices are, engaging students in enrichment activities relevant to their hobbies, and holding a meeting between the social worker or the psychologist with the student to solve his/her problem. In contrast, "Asking sudden questions to the student during lesson" was less important practices to reduce this problem.

Table (9) Descriptive Statistics for the school professional practices to reduce the fourth problem "Truancy $(T)$ "

\begin{tabular}{|c|c|c|c|c|c|}
\hline \multirow{3}{*}{ Items } & \multirow{2}{*}{$\begin{array}{l}\text { All participants } \\
(\mathrm{N}=146)\end{array}$} & \multicolumn{4}{|c|}{ Participants' gender } \\
\hline & & & $=65)$ & fem & $=81)$ \\
\hline & St.D & M & St.D & M & St.D \\
\hline & \multicolumn{5}{|l|}{$.1 p q}$. \\
\hline
\end{tabular}


27. Providing opportunities for students to express their ideas and

$\begin{array}{llllll}3.77 & .42 & 3.72 & .45 & 3.80 & .40\end{array}$
hobbies within the school

28. Providing the tools and the materials that enable the students to $\begin{array}{llllll}3.56 & .55 & 3.52 & .59 & 3.59 & .52\end{array}$ implement their hobbies

29. Registering daily absence in each session

30. Preparing files for students that include their social and personal information

$\begin{array}{llllll}3.51 & .57 & 3.45 & .59 & 3.56 & .55\end{array}$

$\begin{array}{llllll}3.76 & .44 & 3.74 & .48 & 3.78 & .42\end{array}$

31. Following-up the students' behavioural problems daily

32. Organizing seminars to raise awareness of the dangers of truancy

33. Assigning students leading roles in classroom management to $\begin{array}{llllll}3.65 & .59 & 3.62 & .70 & 3.68 & .50\end{array}$ encourage them attend at school

$\begin{array}{llllll}3.54 & .57 & 3.54 & .56 & 3.54 & .57\end{array}$

$\begin{array}{llllll}3.62 & .50 & 3.63 & .49 & 3.60 & .52\end{array}$

Table 9 presents descriptive statistics for the school professional practices for reducing students' Truancy (T) problem. From all participants' perspective, the mean and standard deviation scores shows that all professional practices to reduce students' truancy may be important, such as: "providing opportunities for

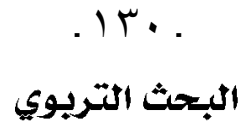




$$
\text { المركن الثومي للبحوث التبويةوالنمية }
$$

students to express their ideas and hobbies within the school", "preparing files for students that include their social and personal information", and "assigning students leading roles in classroom management to encourage them attend at school", $(\mathrm{M}=3.77,3.76 \&$ 3.59 respectively). On the other hand, the results show less important school professional practice registering daily absence in each session, ( $\mathrm{M}=3.51$ respectively).

According to gender, the mean and standard deviation' results revealed a near unanimity among both male and female for the importance of all professional practices, males (M. ranges from 3.45, to 3.74), and females (M. ranges from 3.54, to 3.80). At the same time, participants argue that all professional practices may be important to reduce the truancy problem of students, such as, providing opportunities for students to express their ideas and hobbies within the school, preparing files for students that include their social and personal information, and assigning students leading roles in classroom management to encourage them attend at school. In contrast, registering daily absence in each session was less important practices to reduce this problem.

Table (8) Descriptive Statistics for the school professional practices to reduce the fifth problem "Absenteeism (A)"

Items

34. Distributing students to

$$
\begin{gathered}
\text { All participants } \\
(\mathrm{N}=146)
\end{gathered}
$$$$
\text { M St.D }
$$

Participants' gender

$$
\begin{array}{lrrr}
\multicolumn{2}{c}{\text { male }(\mathrm{N}=65)} & \text { female }(\mathrm{N}=81) \\
M & \text { St.D } & \text { M } & \text { St.D }
\end{array}
$$

3.71 
activities

according to their

needs and interests

35. Preparing guidance

programs for

parents to raise awareness of the seriousness of $\begin{array}{llllll}3.64 & .54 & 3.58 & .61 & 3.68 & .47\end{array}$ absenteeism and its impact on students' achievement

36. Honoring students in the morning queue

$\begin{array}{llllll}3.42 & .56 & 3.40 & .55 & 3.43 & .57\end{array}$

37. Assigning a student to lead a group of school

$\begin{array}{llllll}3.34 & .58 & 3.40 & .55 & 3.28 & .60\end{array}$
activity groups

38. Informing parents of the frequent absenteeism of their sons from school

39. Developing a list of talented students in the school's honor plate

$\begin{array}{llllll}3.59 & .53 & 3.54 & .56 & 3.63 & .51\end{array}$

Table 8 presents descriptive statistics for the school professional practices for reducing students' absenteeism (A) problem. From all participants' perspective, the mean and standard deviation scores shows that all professional practices to reduce students' absenteeism may be important, such as, "distributing students to activities according to their needs and interests", "preparing guidance programs for parents to raise awareness of the






$$
\text { المركن الثومي للبحوث التبويةوالنمية }
$$

seriousness of absenteeism and its impact on students' achievement", and "informing parents of the frequent absenteeism of their sons from school", $(\mathrm{M}=3.66,3.64 \& 3.59$ respectively). On the other hand, the results show less important school professional practice, assigning a student to lead a group of school activity groups, $(\mathrm{M}=$ 3.34 respectively).

According to gender, the mean and standard deviation' results revealed a near unanimity among both male and female for the importance of all professional practices, males (M. ranges from 3.40, to 3.71), and females (M. ranges from 3.28, to 3.68). At the same time, participants argue that all professional practices may be important to reduce absenteeism problem of students, such as, the same professional practices above. In contrast, they also, argue that the assigning a student to lead a group of school activity groups was less important practices to reduce this problem.

Table (9) Descriptive Statistics for the school professional practices to reduce the sixth problem "Dropout $(D)$ "

Items

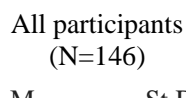
Participants' gender male $(\mathrm{N}=65)$ female $(\mathrm{N}=81)$ $\mathrm{M}$ St.D M St.D M St.D . 
40. Communicating with

youth and social

institutions to

implement

3.48

.57

$3.45 \quad .61$

3.51

.53

recreational activities

for students

41. Discussing the

reasons of students'

dropout in the board

3.45

.62

3.46

.64

3.43

.61

of school trustees

42. Awareness teachers

about the danger of

using corporal

punishment for the

wrong student

43. Instructing teachers

not to ridicule the

students' hobbies

3.68

.48

3.71

.49

3.67

.47

44. Providing additional learning times for under-achievement

3.36

.68

3.43

.71

3.30

.66

students

45. Providing

opportunities for students to practice

3.53

.55

3.54

.59

3.53

.53

their hobbies

46. Raising students'

awareness about the

importance of

3.65

.55

3.55

.64

3.73

.45

obtaining a degree

47. Raising the awareness

for students' parents

about the importance

of their sons

3.59

.51

3.49

.53

3.67

.47

obtaining a degree

Table 9 presents descriptive statistics for the school professional practices for reducing students' dropout (D) problem. From the view of all participants, the mean and standard deviation

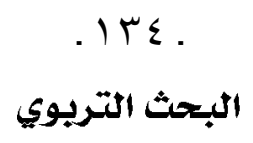




$$
\text { المركن القومي للبحوث التبويةوالتنمية }
$$

scores shows that all professional practices to reduce students' dropout may be important, such as: "instructing teachers not to ridicule the students' hobbies", "raising students' awareness about the importance of obtaining a degree", and "raising the awareness for students' parents about the importance of their sons obtaining a degree", ( $\mathrm{M}=3.68,3.65$, \& 3.59 respectively). On the other hand, the results show less important school professional practices such as, "providing additional learning times for under-achievement students", (M = 3.36 respectively).

According to gender, the mean and standard deviation' results revealed a near unanimity among both males and females for the importance of all professional practices, males (M. ranges from 3.43, to 3.71), and females (M. ranges from 3.30, to 3.73). At the same time, participants argue that all professional practices may be important to reduce Dropout problem of students. While male point out that important professional practices are, instructing teachers not to ridicule the students' hobbies, and raising students' awareness about the importance of obtaining a degree, female point out, raising students' awareness about the importance of obtaining a degree, and raising the awareness for students' parents about the importance of their sons obtaining a degree. In contrast, all participants revealed that the providing additional learning times for under-achievement 
students School pays the tuition fees for students, as a professional practice seems less important to reduce this problem.

Finally, the previous results answered two questions of the current study concerning the following: What are the school professional practices that reduce students' educational problems from the teachers' perspective? Besides, the question: Are there any differences between the views of teachers in the importance of school professional practices that reduce students' educational problems according to participants' Gender?

\section{Discussion}

Experts described a range of interventions, including adaptations to the school context, and providing emotional support to students. In addition, they discussed the important role of multiple stakeholders, and the need for teamwork. Regardless of the interventions used, experts believed they should be tailored to individual needs, and implemented at the first sign of problems (Finning, Harvey, Moore, Ford, Davis, \& Waite, 2018). Moreover, there is little disagreement among specialists about the lack of interest in students inside or outside the classroom, and this is disappointing and weak, and may lead them away from academic matters to activities more nonacceptable of others (Sternberg \& Davidson, 2013).

From this perspective, the present research introduces some school professional practices that the school can offer for students to

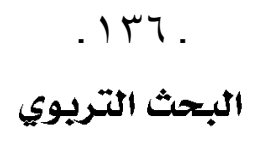




$$
\text { المركن الثومي للبحوث التبويةوالنمية }
$$

reduce their multiple educational problems. The results of this research revealed some professional practices that can be shared by the school community (administrators, teachers and supervisors of educational activities) to reduce students' educational problems. These professional practices can apply by the teachers and all those interested in students, whether inside or outside the school, to reduce their academic problems that may hinder during their staying school period, and may result in dropout from education. This may result in psychological, family and societal pressures that make student neglect homework and his school achievement, hate school community, and leave studying. Then, the society would lose the excellent competencies that may lead to serving the community in the future.

\section{Low achievement problem}

The professional practices which current research were introduced to reduce the students' low achievement are, by using modern technology in teaching, encourage students' participations in classroom activities, and providing a simplified explanation of some subjects of the curriculum by educational experts. These findings were confirmed by some previous studies, results of Awandu (2014) showed that there was a clear misunderstanding by the teachers of what facilitates learning among learners. In this context, Karaduman (2013) stated some interventions that can be performed by school

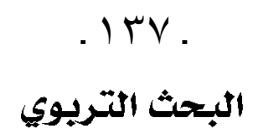


community for preventing underachievement in students from using finding the resources which make them underachievement, communicating with the teacher about the underachiever, communication between students and teachers, and preparing, or applying long lasting guidance programs and consultancy. Musungu \& Nasongo (2008) investigated a study to improve on supervision of teachers' and students' work by using attendance register, and random inspection of pupils' books and assignments.

\section{Cheating problem}

The professional practices which current research were introduced to reduce the students' cheating are, by organizing seminars for students and their parents on the impact of cheating on the individual and society, diversifying test questions, and creating a good climate to prevent cheating during tests through putting educational values, introduce ideal model. These findings were confirmed by Results of Diego's (2017), who suggested that teachers can reduce the problem of cheating by encouraging them to acquire a positive outlook in life, involving them in interesting assignments, helping their students to learn how to summarize and rephrase in their own words, should make clear the acceptable and unacceptable behaviour of the students at the very beginning of the year, stick to it as far as possible, and should make it clear to students that resisting

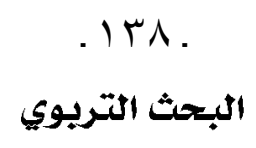




$$
\text { المركن الثومي للبحوث التبويةوالنمية }
$$

temptation to cheat during examinations boosts and builds high selfesteem and self-respect.

\section{Lack of concentration problem}

Results showed several professional practices to reduce this problem by engaging students in enrichment activities, giving opportunities for the student to participate in explaining lesson' subject in the classroom, holding a meeting between the social worker or the psychologist with the student to solve his/her problem, and teacher employed a solving problems style in explaining lessons. These findings were supported by Training and Technical Assistance Center (2017) which stated many interventions to prevent that problem and increase students' attention. These interventions included peer tutoring, cooperative learning, sharing strategies, partner reading, and self-correction opportunities.

\section{Truancy problem}

The current research showed a number of professional practices to reduce this problem by giving students more opportunities to express his/her ideas and hobbies in school, preparing files for students that include their social and personal information, providing the tools and materials that enable student to implement his ideas, assigning students leading roles in classroom management to encourage them attend at school, and organizing symposiums to raise dangers awareness of truancy from school. .119. 
These results were confirmed by Reimer and Dimock (2005), they identified several critical components to prevented truancy by creating a supportive context for learning that includes organizations, community cultures, and policies, and combine meaningful sanctions for truancy and appropriate incentives for attendance to promote proschool attitudes and change their behaviours. Vicki (2008) indicated that school attendance increased, when there is an excessive attendance policy in which learners loses marks after to a particular number of class absences. In the same way, Hanover (2016) examined research-based strategies for addressing truancy in middle and high schools. He suggested that teachers can promote active learning by fostering a sense of competence in students, embracing collaborative learning opportunities, and establishing positive teacher-student relationships.

\section{Absenteeism problem}

Results showed a number of professional practices to reduce this Absenteeism problem, like, distributing students to activities based on their tendencies and interests, preparing guidance programs for parents to raise awareness of the seriousness of absenteeism and its impact on students' achievement, informing parents of the frequent absenteeism of their sons from school. These results were confirmed by some studies, According to Cumbo et al. (2012), they stated that middle schools can implement some policies to reduce

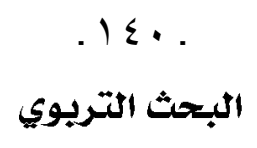




$$
\text { المركن الثومي للبحوث التبويةوالنمية }
$$

student absenteeism through award partial credit for completed course work, although grading based on attendance feels like a good way to reward students for participating in class. And they revealed that it's important to Provide alternatives to out-of-school suspension and expulsion, and they said that school can use Community service, participation in extracurricular activities and field trips should be used as incentives for students. In this context, Kim and Streeter, (2016) identified some professional practices to solve absenteeism problem by involving referring students to school social workers. Providing attendance awards can also be helpful, and not just for perfect attendance. Also, after-school programs that motivate students to attend school in order to participate. These after-school programs can also be educational, covering topics on improving student self-esteem and building social skills. Finally, Kevin and Knoster (2016) stated some interventions, as: Promoting consistent and regular attendance for all students (e.g., explicitly teaching school rules, displaying attendance data, encouraging parents and students to track attendance), providing more routine attendance reports to a student's parents, and conducting comprehensive interventions for students engaging in chronic absenteeism (e.g., functional behavioural assessments, ongoing consultations, and family members). 


\section{Dropout problem}

Results research showed a number of interventions to reduce dropout problem through teacher's guidance not to ridicule the student's hobbies, educating the student and their parents about the importance of obtaining a qualification. These findings were supported by Renzulli and Park (2002), they suggested some strategies to help school members in dropout prevention, as: alter the instructional environment, develop appropriate and supportive school board policies, consider community based collaboration, establish a case management intervention system, and use state-legislated negative-sanction policies. In addition, Dockery's study (2012) suggested some academic interventions, tutoring, academic support, afterschool programming, accelerated credit accumulation and extra classes.

Finally, the most of these interventions were considered especially important for those who had already been absent form school, moving from primary to secondary school, and experts introduced a range of interventions implemented by both teaching and support staff to assist students, including providing emotional support, summer schools, home visits during the holidays, and oneto-one meetings (Finning et al., 2018).

\section{Implications and future research directions}

Findings suggested that there are some school professional practices as recommendations for school community (administrators,

$$
\text { البحث التريوي }
$$




$$
\text { المركن الثومي للبحوث التبويةوالنمية }
$$

teachers and supervisors of educational activities) to support students for confrontation the educational problems which impede their progress, growth of their academic achievement. In addition, these school professional practices may use in schools to support students in reducing the educational problems that they face in school life, and may cause troubles for their academic achievement, and school adjustment. This professional practices such as,

- Employment modern technology in teaching.

- Teacher' diversification of modern teaching strategies.

- Encouraging students to engage in the educational process inside and outside the classroom.

- Diversification of evaluation styles and use computerized tests in the monthly exams.

- Supporting students' participation in various educational activities.

- Support the relationship between school and parents.

- Researchers can conduct future studies on the causes of educational problems for school students.

- Researchers can provide training and awareness programs for students and those concerned, about the risks of educational problems to students, family and society. 


\section{References}

Abu Hawash, R. (2012). Problems of gifted and talented students in Al Baha City from their point of view. International Specialized Educational Magazine. 1(1), 1-16.

Al-Ajaz, F., \& Murtaja, Z. (2012). The reality of gifted and talented students in Gaza governorate and ways to improve it. Journal of the Islamic University for Educational and Psychological Studies, 20(1), 333-367.

Al-Ashwal, A. (2013). Problems experienced by gifted and talented students at the Charter School. Arab Journal of Excellence Development. 4(6), 109 - 136.

Al-Qattan, M., (2016). The academic and psychological problems of gifted students in the intermediate stage in Kuwait, Journal of Faculty of Education, Banha University, 27(107), 186- 208.

Al Sorour, N. (2010). Introduction to the education of the privileged and gifted. Amman: Dar Al Fikr for Printing and Publishing.

Atallah, S. (2008). Low instructional achievement of gifted children survey study. Journal of Research and Educational Studies. 14(24), 81-102.

Athanasoula-Reppa, A., \& Lazaridou, A. (2008). Requirements, roles, and challenges of the principalship in Greece and Cyprus: Newly appointed principals' views. European Education, 40(3), 65-88.

Attar, S. (2012). Problems of outstanding students in the Algerian school. Journal of Humanities and Social Sciences, 8, 169200.

Awandu, G. (2014). Challenges faced by gifted and talented learners in academic performance in schools in Kenya. University of Nairobi.

Badarna, L. (2016). Role of School Administration in Solving Students' Problems among Bedouin Schools within the Green Line in Palestine. Journal of Education and Practice, 7(6), 182-190.

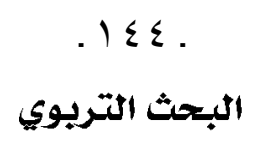




$$
\text { المركن القومي للبحوث التبوبةوالنمية }
$$

Bai, S., \& Repetti, R. (2018). Negative and positive emotion responses to daily school problems: Links to internalizing and externalizing symptoms. Journal of abnormal child psychology, 46(3), 423-435.

Balfanz, R., \& Byrnes, V. (2012). The importance of being in school: $A$ report on absenteeism in the nation's public schools. Baltimore: Johns Hopkins University Centre for Social Organization of Schools.

Benner, A., \& Graham, S. (2009). The transition to high school as a developmental process among multiethnic urban youth. Child development, 80(2), 356-376.

Bou Abdullah, L. \& Nani, N. (2008). Sponsorship of talent under the systemic approach. Human Resources Development Journal, 6, 79-98.

Chirtes, G (2010). A case study into the causes of school dropout. Acta Didactica Napocensia. 3(4), 25-34.

Cumbo, G., Burden H., \& Burke I. (2012). Truancy Reduction: Research, Policy and Practice". Center for Children and Youth Justice. Retrieved from http://ccyj.org/wpcontent/uploads/2015/04/TRUANCY_Resource-withpublication-date.pdf

Dahiya, S. (2015). Academic cheating among students: pressure of parents and teachers. International Journal of Applied Research, 1(10): 793-797.

David, H. (2017). A double label: Learning disabilities and emotional problems among gifted children. International Letters of Social and Humanistic Sciences, 75, 22-31.

Diego, L. (2017). Friends with Benefits: Causes and Effects of Learners' Cheating Practices During Examination. IAFOR Journal of Education, 5(2), 121-138.

Dockery, D. (2012). School dropout indicators, trends, and interventions for school counselors. Journal of school counseling, 10(12), 12. 
Finning, K., Harvey, K., Moore, D., Ford, T., Davis, B., \& Waite, P. (2018). Secondary school educational practitioners' experiences of school attendance problems and interventions to address them: a qualitative study. Emotional and Behavioural Difficulties, 23(2), 213-225.

Grewal, D. (2014). Improving concentration and mindfulness in learning through meditation. J. Humanit. Soc. Sci, 19, 33-39.

Hanover, R. (2016). Best practices for improving attendance secondary schools. Hanover Research. District Administration Practice. Available at: www.HanoverResearch.com

Hartman, E. (2016). Factors influencing dropout behaviour of gifted students: The influence of giftedness indicators and environmental, personal, and demographical factors on gifted students' dropout behaviour in giftedness programs (Master's thesis, University of Twente).

Karaduman, G. (2013). Underachievement in Gifted Students. International Journal on New Trends in Education and Their Implications, 4(4), 165-172.

Kearney, C. (2008). School absenteeism and school refusal behaviour in youth: A contemporary review. Clinical Psychology Review, 28, 451-471.

Kevin C., \& Knoster, M. (2016). Strategies for Addressing Student and Teacher Absenteeism: A Literature Review. North central comprehensive Center. Nebraska.

Kim, J., \& Streeter, C. (2016). Strategies and interventions for improving school attendance. In Encyclopedia of Social Work.

Kocak, M. (2016). The Role of Prep Schools in the Middle to High School Transition of Students in Southeastern Turkey. Doctoral dissertation, University of South Florida.

Manning, S. (2006). Recognizing Gifted Students: A Practical Guide for Teachers. Kappa delta pi record, 64-68. http://files.eric.ed.gov/fulltext/EJ724632.pdf

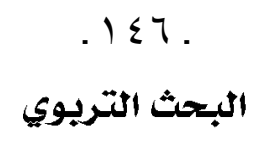




\section{المركن القومي للبحوثالنبوبةوالنمية}

Maynard, B., McCrea, K., Pigott, T., \& Kelly, M. (2013). Indicated truancy interventions for chronic truant students: A Campbell systematic review. Research on Social Work Practice, 23, 521.

Musungu, L. \& Nasongo, J. (2008). The head-teacher's instructional role in academic achievement in secondary schools in Vihiga district, Kenya. Educational Research and Review, 3 (10), 316-323.

Neihart, M., Reis, S., Robinson, N. \& Moon, S. (2002). The Social and Emotional Development of Gifted Children What Do We Know? The National Association for Gifted Children: USA.

Peters, Willy A., Grader-Loidl, Helga, S., \& Patrica, A. (2000). Underachievement in Gifted Children and Adolescents: Theory and Practice. 609-621, in: (Ed. Kurt A. Heler, Franz J. Monks, Robert J. Stenberg, Rena F. Subotnik). International Handbook of Giftedness and Talent. $2^{\text {th }}$ Ed. Oxford: Elsevier Science Ltd.

Rayneri, L., Gerber, B., \& Wiley, L. (2003). Gifted achievers and gifted underachievers: The impact of learning style preferences in the classroom. Journal of Secondary Gifted Education, 14(4), 197-204.

Reimer, M., \& Dimock, K. (2005). Best practices and model truancy programs. Clemson, SC: National Dropout Prevention Center/Network, Clemson University.

Reis, S. \& McCoach, D. (2000). The Underachievement of Gifted Students: What Do We Know and Where Do We Go? Gifted Child Quarterly. National Association for Gifted Children. Reprinted with Permission. 44(3), 152-170.

Renzulli, J., \& Park, S. (2002). Giftedness and High School Dropouts: Personal, Family, and School-related Factors. University of Connecticut. Storrs, Connecticut.

Rimm, S. (2003). Gifted Education-Guidance for parents and teachers. (Translated by: Adel Abdullah). Cairo: Dar AlRashad. 
Rimm, S. (1987). Why bright children underachieve: the pressures they feel, indiana state department of education office, Purdue Univ., West Lafayette, IN. Gifted Education Resource Inst. 24 Aug $1987 . \quad$ Retrieved from http://files.eric.ed.gov/fulltext/ED323691.pdf

Sadiq, A. \& Abu Hatab, F. (1999). Human Development from the fetus to the elderly, $4^{\text {th }}$ Ed. Cairo: The Anglo-Egyptian Library.

Saratawi, A., Duqmaq, S., \& Abu Helal, M. (2009). Behavioral problems among students in the preparatory and secondary public schools in United Arab Emirates. Faculty of Education Journal, UAE University. 26, 39-75.

Shiferaw, S., Fantahun, M., \& Bekele, A. (2006). Psychosocial problems among students in preparatory school, in Dessie town, north-east Ethiopia. Ethiopian Journal of Health Development, 20(1), 47-55.

Sternberg, R. \& Davidson, J. (2013). Concepts of giftedness. 2Ed, (Translated by: Qurna, D., Dababnah, Kh. \& Bataina, O.). Riyadh: Obekan publisher.

Tannenbaum, A. (2000). A History of Giftedness in School and Society, in, Heller, K. (Ed): International Handbook of Giftedness and Talent - $2^{\text {nd }}$ Ed, pp. $23-53$, Elsevier, Oxford, UK.

Timmons, A., \& Margolin, G. (2015). Family conflict, mood, and adolescents' daily school problems: Moderating roles of internalizing and externalizing symptoms. Child Development, 86(1), 241-258.

Training and Technical Assistance Center (2017). Classroom Interventions for Attention Deficit/ Hyperactivity Disorder Considerations Packet. Retrieved from

http://education.wm.edu/centers/ttac/

Trujillo, L. (2006). School truancy: A case study of a successful truancy reduction model in the public schools. UC Davis Journal of Juvenile Law and Policy, 10, 69-95.






$$
\text { المركن القومي للبحوث التبوبةوالنمية }
$$

Vicki, P. (2008). The perceptions of new principals regarding the knowledge and skills important to their initial success. NASSP bulletin, 92(3), 224-250.

Wilkinson J. (2009). Staff and student perceptions of plagiarism and cheating. International Journal of Teaching and Learning in Higher Education, 20(2):98-105.

Zahran, H. (2005). Developmental psychology, "Childhood \& Adolescence", $6^{\text {th }}$ Ed. Cairo: Alam AlKotob. 